\title{
Social welfare related to AIDS in Brazil: factors associated with social assistance and social security, $2004-2016$
}

\author{
Keile Aparecida Resende Santos, ${ }^{1}$ Luciomar de Melo, ${ }^{1}$ Antônio Marcos \\ Machado de Oliveira, ${ }^{2}$ and Jean Ezequiel Limongi ${ }^{2}$
}

Suggested citation Resende Santos KA, de Melo L, Machado de Oliveira AM, Limongi JE. Social welfare related to AIDS in Brazil: factors associated with social assistance and social security, 2004 - 2016. Rev Panam Salud Publica. 2018;42:e73. https://doi.org/10.26633/RPSP.2018.73

ABSTRACT Objective. To describe the occurrence of social welfare benefits related to AIDS in Brazil and to compare the characteristics of the beneficiaries of social assistance and social security in $2004-2016$.

Methods. This was an observational, analytical study based on secondary data obtained from the Ministry of Social Security of Brazil. Sociodemographic and epidemiologic characteristics of the beneficiaries of AIDS-related social assistance and social security were analyzed.

Results. From 2004 - 2016, a total of 99369 benefits were granted, the majority of which were sick pay (64\%), followed by social assistance benefits $(26.5 \%)$ and disability retirement $(8.1 \%)$. At the time that benefits were initiated, 51\% of the individuals were unemployed. Those living in urban areas, females, the young, the elderly, and residents of the North and Northeast received more social assistance benefits. Duration of social assistance benefits (average 4589 days) was greater than that of social security benefits (302 days). Survival among women (578 months) was greater than among men (311 months).

Conclusions. In Brazil, the profile of social welfare beneficiaries living with AIDS reveals their social vulnerability. Controlling AIDS should be a priority on public agendas, aiming to minimize the disease's social and economic impact, especially on public health, social security, and social assistance.

Keywords Acquired Immunodeficiency Syndrome; HIV; social welfare; social security; social assistance; Brazil.

Since its recognition in 1981, human immunodeficiency virus (HIV)/acquired immune deficiency syndrome (AIDS) has been a serious public health problem worldwide, especially in developing

\footnotetext{
Instituto Nacional do Seguro Social, Uberlândia, Minas Gerais, Brazil.

2 Universidade Federal de Uberlândia, Uberlândia, Minas Gerais, Brazil. Send correspondence to Jean Ezequiel Limongi, jeanlimongi@gmail.com
}

countries. Globally, about 37 million people live with HIV / AIDS in 186 countries (1). The disease burden varies considerably among different regions and countries (1).

In Brazil, 842710 cases of AIDS have been reported from 1980 (when the first case was recognized) to June 2016 (2). In the last 10 years, the average annual rate has stabilized at 20.7 cases per 100000 inhabitants. The distribution in the country is also heterogeneous, as the Southeast and South experience a greater portion, shouldering $53.0 \%$ and $20.1 \%$ of the cases, respectively (2).

Since the beginning of the epidemic in Brazil, 303353 AIDS-related deaths have been identified (2). However, the country has seen a gradual increase in the survival rate. The median survival for cases diagnosed in the 1980s was 5 months (3). In a cohort of patients diagnosed in 
1995 - 1996 throughout Brazil, the survival rate had risen to 36 months (3). In another cohort initiated in 1998 - 1999 in just the South and Southeast, the survival rate had grown to 108 months (4). Currently, the life expectancy for young individuals without any opportunistic infections is $>50$ years of age. The use of antiretroviral therapy has been the main cause of this increase (5).

In Brazil, public health is provided by the Unified Health System (SUS), along with social security and social assistance. These are the three pillars of its social welfare system. The pillars constitute rights guaranteed by the 1988 Federal Constitution of Brazil, in which social security is funded by contributions, while social assistance and public health are funded by the Government of Brazil (6).

Social welfare plays an important role in the history of AIDS in the country. Its policies regarding prevention, treatment, social security, and social assistance for patients were supported and implemented with the participation of state governments, researchers, and social movements $(7,8)$. Given the magnitude and the transcendence of AIDS in Brazil, this study aims to describe the country's AIDS-related social welfare benefits and to compare the characteristics of the beneficiaries of social assistance and social security in $2004-2016$.

\section{MATERIALS AND METHODS}

This was an observational, analytical study conducted with secondary data obtained from the Sistema Único de Informações de Benefícios (Unified System of Benefits Information; SUIBE) maintained by the Ministry of Social Security and Assistance of Brazil. This information system is not freely accessible and is composed of the beneficiaries' sociodemographic and epidemiologic data. It is used to collect statistical data from the country's social security system. The data were obtained through express authorization from the National Institute of Social Security. SUIBE is an information system with a high degree of reliability; however, individualized data were again verified at the time of the research, guaranteeing greater consistency.

\section{Analysis}

This study analyzed the following variables: sex, current age, start of benefits, age group, area of residence, geographic region, occupational situation (employed/unemployed), type of benefit received, duration of benefits (in days), duration of contributions to social security, salary range, date of disease onset, date of beginning of disability, and date of death. The specific age groups, in years, were: $0-14,15-19,20-39,40-$ 59 , and $60-79$. The dichotomous variable benefits (social security $x$ social assistance benefits) was created for the bivariate analysis. The chi-square test and multiple logistic regression with dummy variable (for variables with more than two categories) were employed, considering the Odds Ratio with 95\% Confidence Intervals as a measure of association. The Kruskal-Wallis test was used to compare numerical variables. The level of significance adopted was 5\%. The curve of Kaplan Meier was employed for survival analysis, and the Log-Rank test was employed to compare the survival distributions.

The software, Epi Info ${ }^{\mathrm{TM}}$ version 7.1.5 (Centers for Disease Control and Prevention, Atlanta, Georgia, United States) was used for all the analyses. The Geographic Information System, QGIS version 2.18 (Open Source Geospatial Foundation, Chicago, Illinois, United States) was used for data spatialization, enabling the development of the mosaic map.

\section{Ethics}

This work was approved by the Research Ethics Committee of the Federal University of Uberlândia, Minas Gerais, Brazil (Register no. 1.427.726/ 2016). The Worker's Identification Number (NIT), a variable that identifies individuals in the SUIBE, was excluded from the database to ensure the anonymity of individuals.

\section{RESULTS}

During the study period (2004 - 2016), a total of 99369 benefits were granted, predominantly to males $(65 \%)$, in the age group $20-39$ years $(49.8 \%)$, living in urban areas $(97.4 \%)$. The distribution of benefits across the country's geographic regions followed the same trend as the number of confirmed cases of AIDS (Figure 1). Sick pay was the main benefit granted (64\%), followed by social assistance benefits (26.5\%) and disability retirement $(8.1 \%)$. Based on the time interval between the date of disease onset
(DDO) and the date of beginning of disability (DBI), $50 \%$ of the population studied was incapacitated up to 9 months after DDO; $23.7 \%$ was found incapacitated upon DDO.

The average age of sick individuals was $36 \pm 10$ years. The average age of disabled individuals was $39 \pm 9.0$ years. A contribution time of $\leq 15$ years was predominant $(91 \%)$, with an average of $5.0 \pm$ 6.0 years. At benefit initiation, $51 \%$ of the individuals were unemployed; of the employed individuals, $75 \%$ were working in commerce. Most beneficiaries were receiving $1-2$ times the minimum wage $(75 \%)$, with a mean of $1.5 \pm 1.0$. The geographic regions with the greatest incidence were the Southeast (43\%) and the South $(23 \%)$.

As shown in Table 1, women were more likely to receive social assistance benefits than men were $(\mathrm{OR}=2.08)$. Individuals living in urban areas were 12 times more likely to receive benefits than those in rural areas. In the younger age groups, social assistance benefits were more frequent $(0-14$ years, $92.9 \%$; $15-19$ years, $68.5 \%)$ than in the older one $(60-79$ years, $33.5 \%)$. The age group $20-39$ years, compared to the $0-14$ year group, was $98 \%$ less likely to receive these benefits. The occurrence of social assistance benefits was also more frequent in the North $(\mathrm{OR}=3.68)$ and Northeast $(\mathrm{OR}=2.8)$. Recipients of AIDS-related social assistance benefits tended to be younger than those receiving social security benefits and had less monetary assistance; they also had less social security contribution time and their duration of benefits was significantly greater (Table 2).

The survival curve was calculated for the 67495 cases for which DDO and/or date of death information was available. During the period analyzed, there were more deaths among men (13 658; 70.5\%) than women $(5705 ; 29.5 \%)$. The general median survival was 331 months; for men, 311 months, and for women, 578 months. As show in Figure 2, after 450 months of diagnosis, there were about $55 \%$ and $32 \%$ of surviving women and men, respectively $(P<0.000001)$.

The duration of benefits analysis found that social assistance benefits were being granted for a longer period (median of 4589 days) than social security benefits (median of 302 days). As shown in Figure 3, after 3600 days, social assistance benefits were still active in $57 \%$ of 
FIGURE 1. Distribution of confirmed cases of AIDS and Social Welfare benefits (social assistance and social security) granted in Brazil, by geographic region, $2004-2015^{a}$

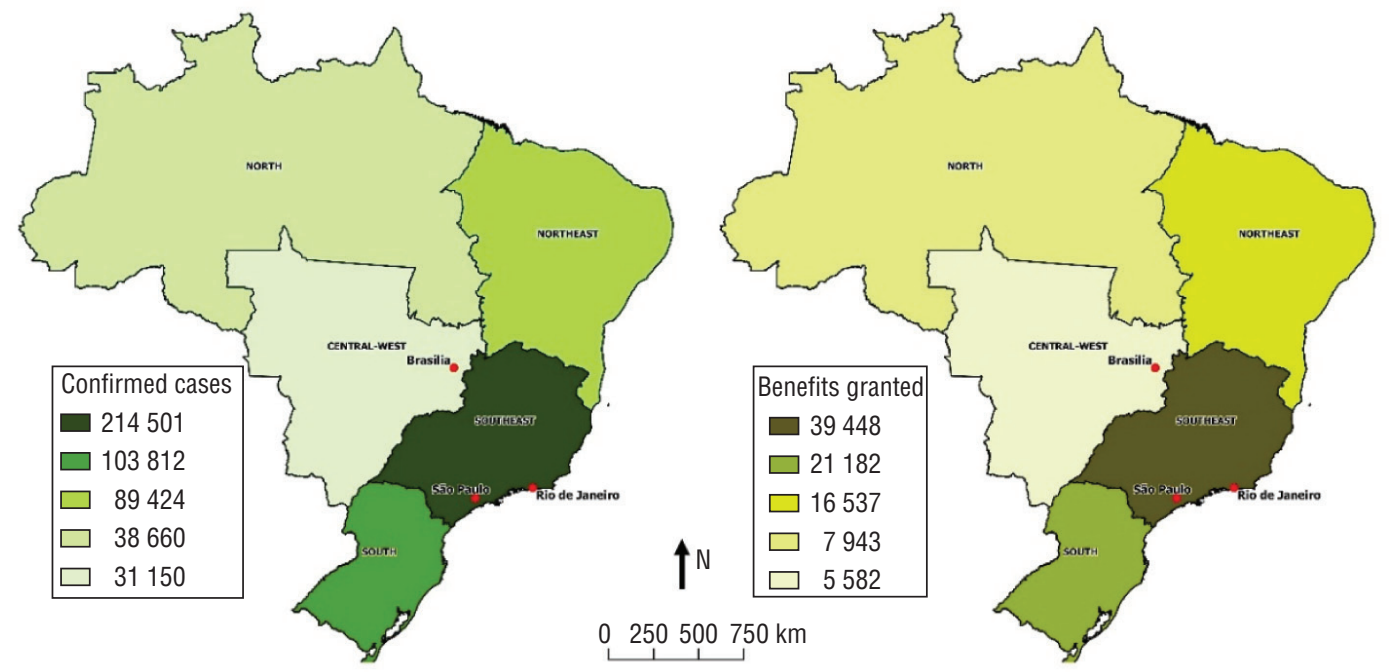

a Full details of confirmed cases unavailable for 2016.

Source: Prepared by the authors from the study results and data from the Brazilian Institute of Geography and Statistics.

Note: Map produced using QGIS version 2.18 (Open Source Geospatial Foundation, Chicago, Illinois, United States). Source of shapefile: Brazillian Institute of Geography and Statistics (Rio de Janeiro, Brazil).

TABLE 1. Characteristics of people with AIDS receiving social welfare benefits in Brazil, $2004-2016$

\begin{tabular}{|c|c|c|c|c|c|c|c|}
\hline \multirow{2}{*}{ Characteristics } & \multicolumn{2}{|c|}{ Social Security benefits } & \multicolumn{2}{|c|}{ Social Assistance benefits } & \multirow{2}{*}{$\begin{array}{c}\text { Odds Ratio } \\
\text { (95\% Confidence Interval) }\end{array}$} & \multirow{2}{*}{$\begin{array}{l}\text { Chi-square value or } \\
\text { Z-statistic }\end{array}$} & \multirow{2}{*}{$P$ value } \\
\hline & $n$ & $\%$ & $n$ & $\%$ & & & \\
\hline \multicolumn{8}{|l|}{$\overline{\text { Sex }}$} \\
\hline Male & 50889 & 78.7 & 13765 & 21.3 & 1 & & $<0.00001$ \\
\hline Female & 22178 & 63.9 & 12537 & 36.1 & $\begin{array}{c}2.08 \\
(2.03-2.15)\end{array}$ & 2549.43 & \\
\hline \multicolumn{8}{|c|}{ Age range, ${ }^{a}$ in years } \\
\hline $0-14$ & 127 & 7.1 & 1658 & 92.9 & 1 & & \\
\hline $15-19$ & 150 & 31.5 & 327 & 68.5 & $\begin{array}{c}0.17 \\
(0.12-0.21)\end{array}$ & 13.27 & $<0.00001$ \\
\hline $20-39$ & 37178 & 75.1 & 12330 & 24.9 & $\begin{array}{c}0.02 \\
(0.02-0.03)\end{array}$ & 39.72 & $<0.00001$ \\
\hline $40-59$ & 33933 & 75.3 & 11144 & 24.7 & $\begin{array}{c}0.03 \\
(0.02-0.03)\end{array}$ & 39.64 & $<0.00001$ \\
\hline $60-79$ & 1675 & 66.5 & 843 & 33.5 & $\begin{array}{c}0.04 \\
(0.02-0.05)\end{array}$ & 32.14 & $<0.00001$ \\
\hline \multicolumn{8}{|l|}{ Area of residence } \\
\hline Rural & 2526 & 97.0 & 76 & 3.0 & 1 & & - \\
\hline Urban & 70541 & 72.9 & 26226 & 27.1 & $\begin{array}{c}12.3 \\
(9.8-15.7)\end{array}$ & 760.03 & $<0.00001$ \\
\hline \multicolumn{8}{|c|}{ Geographic region ${ }^{\mathrm{a}}$} \\
\hline South & 18660 & 81.0 & 4365 & 19.0 & 1 & & - \\
\hline North & 4787 & 53.8 & 4115 & 46.2 & $\begin{array}{c}3.68 \\
(3.48-3.87)\end{array}$ & 48.02 & $<0.00001$ \\
\hline Northeast & 11247 & 60.0 & 7386 & 40.0 & $\begin{array}{c}2.8 \\
(2.69-2.93)\end{array}$ & 45.84 & $<0.00001$ \\
\hline Southeast & 33965 & 80.0 & 8680 & 20.0 & $\begin{array}{c}1.09 \\
(1.05-1.14)\end{array}$ & 4.28 & $<0.00001$ \\
\hline Midwest & 4408 & 71.5 & 1756 & 28.5 & $\begin{array}{c}1.70 \\
(1.60-1.82)\end{array}$ & 16.20 & $<0.00001$ \\
\hline
\end{tabular}

a Z-statistic.

Source: Prepared by the authors from the study results. 
TABLE 2. Sociodemographic variables for individuals with AIDS receiving social welfare benefits in Brazil, $2004-2016$

\begin{tabular}{|c|c|c|c|c|}
\hline \multirow{2}{*}{ Characteristics } & Social Security Benefits & Social Assistance Benefits & \multirow{2}{*}{ Kruskal-Wallis $\mathrm{H}$ value } & \multirow{2}{*}{$P$ value } \\
\hline & Median (min-max) & Median (min-max) & & \\
\hline Age at beginning of disability, in years & $39(0-81)$ & $38(0-71)$ & 283.89 & $<0.00001$ \\
\hline Current age, in years & $45(0-88)$ & $44(1-82)$ & 444.28 & $<0.00001$ \\
\hline Years of contribution & $5(0-38)$ & $0(0-28)$ & 47602.74 & $<0.00001$ \\
\hline Initial monthly income (number of minimum wages) & $1.21(1-8.78)$ & $1(1-1)$ & 28886.35 & $<0.00001$ \\
\hline
\end{tabular}

Source: Prepared by the authors from the study results.

FIGURE 2. AIDS survival analysis, by sex, Brazil, $2004-2016$

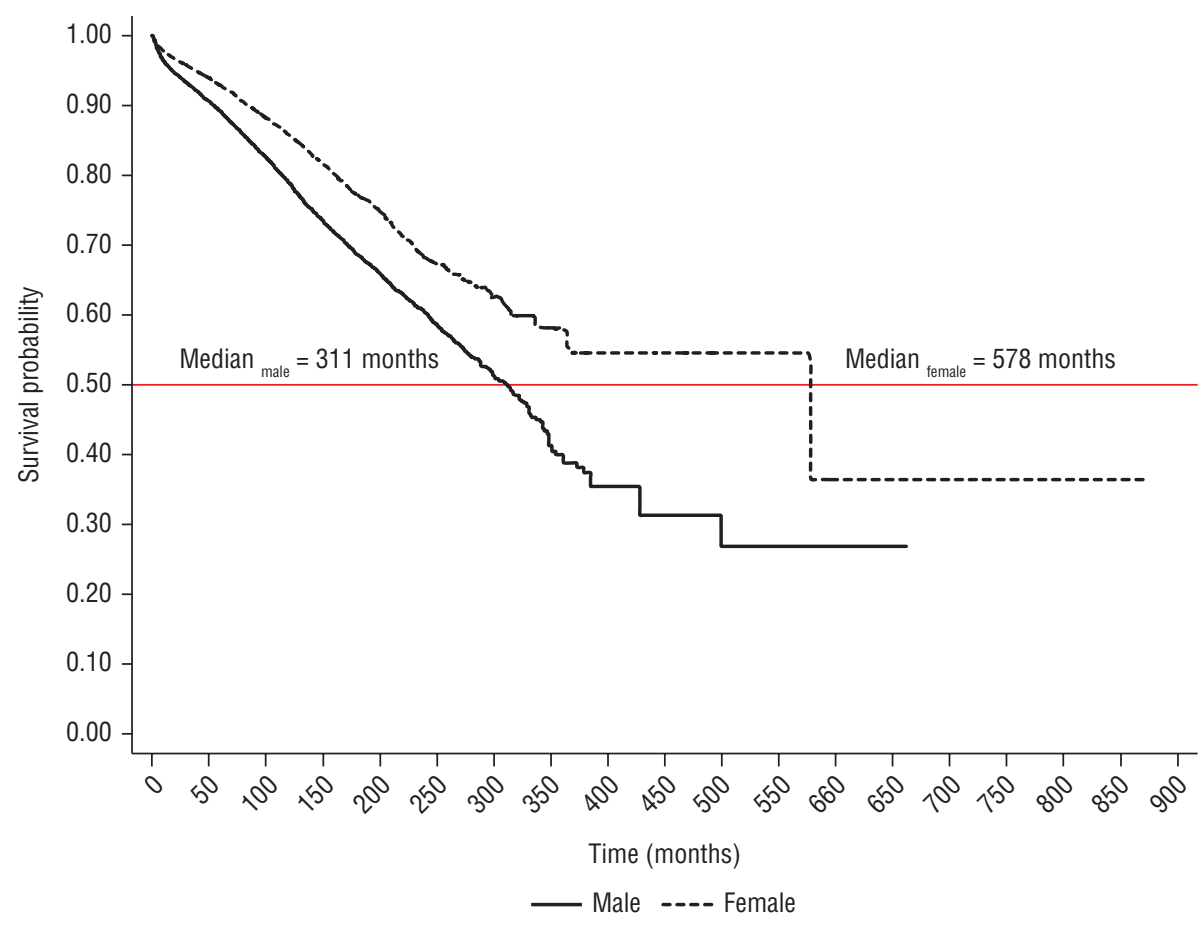

Source: Prepared by the authors from the study results.

cases, whereas social security benefits represented only $8 \%(P<0.000001)$.

\section{DISCUSSION}

In Brazil, there were 493435 AIDS cases reported from January 2004 - June 2016 (2). During the same period, a total of 99369 AIDS-related social security and social assistance benefits were granted. There are a variety of reasons that explain the discrepancy between reported cases and benefits. The individuals might not have proven their need in terms of the poverty criteria required for social assistance benefits (9). As to social security benefits, the individual may not have met the insurance criteria. Or, because AIDS is a progressive disease, the individual's observable symptoms may not have triggered a work disability (10). Another probable reason for the discrepancy is due to a lack of access to information regarding assistance available by law. Moreover, the great variability in types of work activities may result in individuals being able to retain employment despite the illness. The fact that an incapacity to work was confirmed in $23.7 \%$ of individuals at the time of diagnosis, and in 50\% within 9 months, points to late diagnosis as well as non-adherence to antiretroviral therapy (11).

The short social security contribution time associated with a large proportion of unemployed individuals showed that a significant number of people living with AIDS in Brazil are socially vulnerable. Moreover, the benefit granted, on average
1.5 times the minimum wage, hardly guarantees a good quality of life (11).

The highest concentration of AIDS in Brazil, based on reported cases from January 1980 - June 2016 (2), was among those 25 - 39 years of age for both men (53.0\%) and women (49.4\%). The concentration of cases in this age group and the lengthy absences from work caused by AIDS heightens its social impact. In this study, $49.8 \%$ of beneficiaries belonged to this age group. By contrast, only $2.5 \%$ of the individuals were elderly; however, $45.4 \%$ were in the age group $40-59$ years.

Brazil is undergoing a rapid demographic transition. Greater survival rates and an aging population are challenging the health and social welfare systems (12). In addition, the incidence of AIDS among the elderly has increased in recent years (13). In this context, the aging of patients with AIDS, as well as the emergence of new cases among the elderly, greatly impacts all three of Brazil's social welfare pillars-public health, social security, and social assistance.

In the early 1980s, the first cases of AIDS were identified in Brazil, namely in São Paulo and Rio de Janeiro. The epidemic hit all areas of the country, though in a heterogeneous way, with most cases concentrated in the Southeast, in the state capitals, and in coastal cities (14). According to the Brazilian Institute of Geography and Statistics, in 2010, the Southeast, Northeast, and South were the most populous areas (15). This study showed that in the Southeast and South, fewer social assistance benefits were granted than social security benefits, compared to other regions.

Furthermore, throughout the country, AIDS-related social assistance benefits were granted mostly to females. These findings support data from the Ministry of Labor and Employment that shows that in the Southeast and South, where there is the greatest number of formal jobs, most jobs are held by males (16). Overall, social 
FIGURE 3. AIDS survival analysis according to duration of Social Welfare benefits (in days), Brazil, $2004-2016$

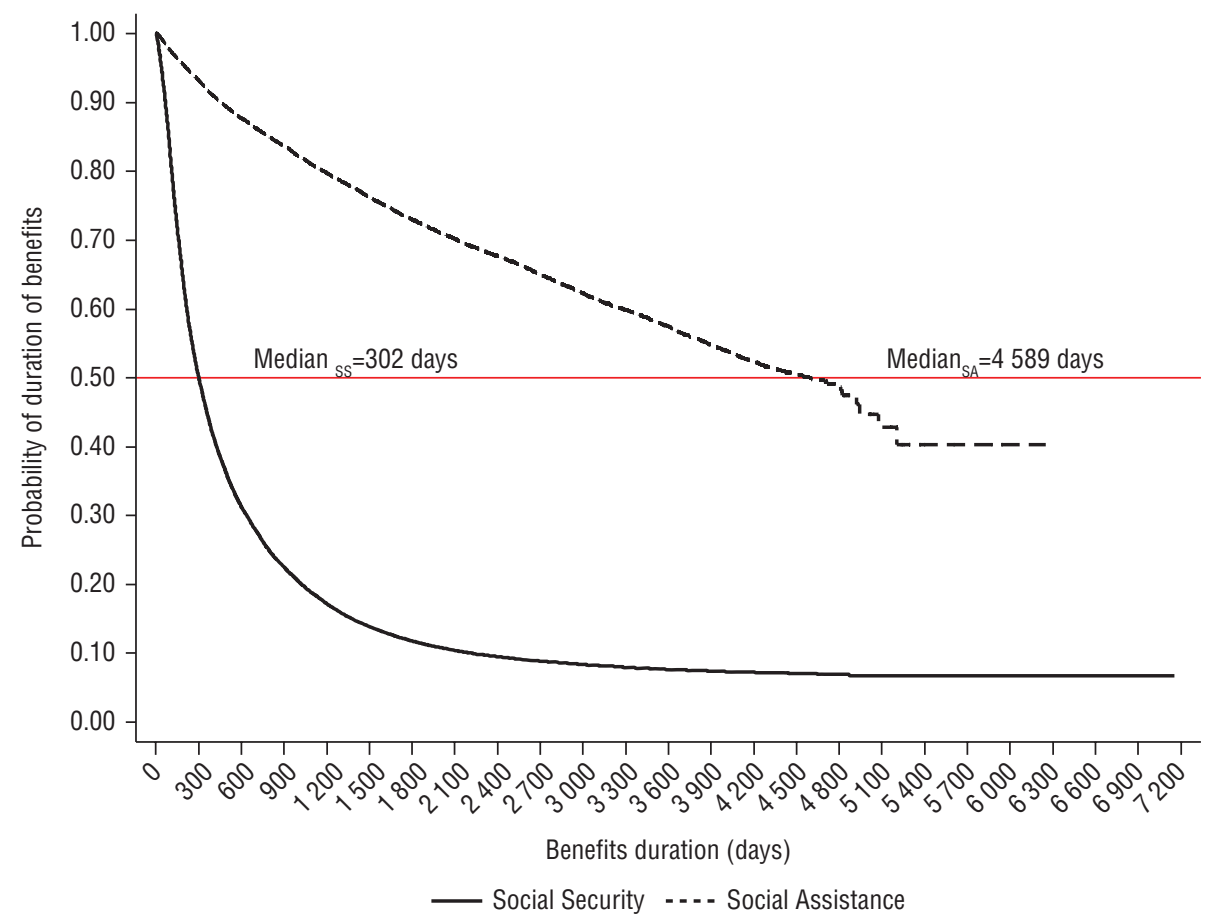

Source: Prepared by the authors from the study results.

welfare in Brazil, and specifically, AIDSrelated benefits, show persistent inequalities between men and women in the labor market, though at an increasingly lower proportion. Women still make up the majority of unpaid family workers. Such disparity in sex and quality of work leads to women's limited access to work-related social protections. Lower rates of formal remuneration and a reduced number of hours and years of work with social protections have negative consequences (17).

This study found that individuals residing in rural areas received less social assistance benefits than those in urban areas. According to Brazilian law, social assistance benefits are granted to individuals who can prove that they cannot provide for themselves or be supported by their families. Individuals living in rural areas can often subsist on crops, while those in urban areas do not have such options; thus, they seek and are granted social assistance benefits. Furthermore, the rural population often has a lower level of education and difficulty accessing social and health services due to isolation and lack of public transportation (18). Therefore, the reduced number of benefits claims in rural areas could be associated with a lack of knowledge about the law and the assistance to which the disabled are entitled.
The number of deaths was higher among men (70.5\%). Men also had a shorter survival time (311 months) than women. This higher mortality rate among men is well reported in the literature in almost all age groups and for almost all causes, focusing attention on issues related to biological (sex) and behavioral (gender) factors (19). The overall median survival for beneficiaries was 331 months, considerably longer than that reported by previous studies in Brazil: in the 1980s, 5 months; 1995 - 1996, 36 months; and in $1998-1999,108$ months $(3,4)$. The public policies implemented in Brazil in this period, mainly the use of antiretroviral therapy, contributed substantially to these results (20).

Social assistance benefits, although less frequent, had a significantly longer duration. This can be explained, in part, by the continued precarious conditions of the beneficiaries, but also by the lack of biannual reviews that should be performed by the social welfare system to verify the continued need for benefits $(9,21)$.

Since 2013, as recommended by the World Health Organization (WHO), all individuals with HIV in Brazil, regardless of CD4 cell count, receive antiretroviral therapy. This strategy improves individuals' life expectancy and lowers the risk of viral transmission (22). In addition, in 2017, Brazil became one of the first countries in the world to begin providing free access to Dolutegravir, a retroviral drug recommended by WHO for treating HIV / AIDS. Currently, the Government of Brazil has an annual drug expenditure of over US\$ 351 MM (23). With timely diagnosis, access to current medications, and adherence to treatment, those with recentlyacquired HIV infections may have a life expectancy nearly equal to an HIVnegative individual, surpassing 50 years in some estimates $(24,25)$. Given the advances achieved in AIDS therapy in recent years, it is expected that there will be a decrease in the number of individuals who must leave work due to the illness.

Currently, Brazil faces two significant burdens: public health (spending on prophylaxis, medications, and hospitalizations of patients) and granting long-term benefits. However, besides improving the health and life expectancy of individuals with AIDS, there is a need to reduce the stigma of the disease, especially in relation to the work market. Since 2010, the Ministry of Labor and Employment has banned HIV testing of workers and prospective employees in order to avoid any workrelated discriminatory or restrictive practices (26).

To legally assess an incapacity for work, the courts in Brazil also consider the social stigma of the disease, not just the individual's clinical status. The recommendation of the Federal Special Courts is as follow: "Proven that the benefit applicant is HIV positive, it is up to the judge to verify the claimant's personal, social, economic, and cultural conditions, in order to analyze the disability in a broad sense, given the high social stigmatization of the disease" (27).

In Brazil, there are different epidemiologic profiles of AIDS related to the geographic and structural diversity of the country. In general, the North and Northeast and medium-sized municipalities have growing epidemics and a low response capacity, while the Southeastern and South and the largest urban centers have brought epidemics under control (28). The great cultural, demographic, economic, and social diversity of the country can mask regional inequalities in both reporting of AIDS cases as well as access to social welfare services (14).

Limitations. An important study limitation was the absence of a variable for the underlying cause of "incapacity for 
work" in the SUIBE database. In addition, although "education" exists in SUIBE, there was no data recorded for this sociodemographic variable. It is also worth noting that this study did not include the large number of workers who do not have formal employment contracts and/ or do not contribute to social security. In 2011, $28.3 \%$ of employees were "informal" and $23.5 \%$ made no social security contribution. For employers and the self-employed, it was even higher, at $76.1 \%$ and $72 \%$, respectively (16). Also excluded from this analysis were government and military personnel.

. Ortblad KF, Lozano R, Murray CJL. The burden of HIV: insights from the Global Burden of Disease Study 2010. AIDS. 2013;27(13):2003-17.

2. Brasil. Secretaria de Vigilância em Saúde, Ministério Da Saúde. Bol Epidemiol HIV AIDS. Brasília. 2017; 5(1).

3. Marins JRP, Jamal LF, Chen SY, Barros MB, Hudes ES, Barbosa AA, et al. Dramatic improvement in survival among adult Brazilian AIDS patients. AIDS. 2003;17(11):1675-82.

4. Guibu IA, Barros MBA, Donalisio MR, Tayra A, Alves MCGP. Sobrevida de pacientes com AIDS das regiões Sudeste e Sul do Brasil: análise da coorte de 1998 a 1999. Cad Saude Publica. 2001;27:s79-92.

5. Barros SG de, Vieira-da-Silva LM. A terapia antirretroviral combinada, a política de controle da Aids e as transformações do Espaço Aids no Brasil dos anos 1990. Saúde Em Debate. 2017;41(3):114-28.

6. Brasil. Constituição da República Federativa do Brasil, de 5 de outubro de 1988. Constituição da República Federativa do Brasil. Brasília: Senado Federal; 1988.

7. Granjeiro A, Laurindo Da Silva L, Teixeira PR. Resposta à AIDS no Brasil: Contribuições de movimentos sociais e da reforma sanitária. Rev Panam Salud Publica. 2009;26(1):87-94.

8. Barros SG, Vieira da Silva LM. A gênese da política de luta contra a aids e o Espaço Aids no Brasil (1981-1989). Rev Saude Publica. 2016;50(43).

9. Brasil. Lei ${ }^{\circ} 8742 / 93$ de 07 de dezembro de 1993. Dispõe sobre a organização da Assistência Social e dá outras providências. Diário Oficial da União, Brasília, DF; 7 December 1993. Available from: www. planalto.gov.br/ccivil_03/Leis/L8742. htm Accessed 8 October 2015.

10. Brasil. Decreto 3048/99 de 06 de maio de 1999. Aprova o Regulamento da Previdência Social, e dá outras providências. Diário Oficial da União, Brasília, DF; 6 May 1999. Available from: www.planalto.gov.br/ccivil_03/decreto/d3048.htm Accessed 8 October 2015.

11. Gimeniz Galvão MT, Lima Soares L, Citó Pedrosa S, Teles Fiuza ML, de Araújo Lemos L. Quality of life and adherence

\section{Conclusions}

This study found that AIDS in Brazil is affecting an undue number of male workers at their most productive stage of life, mostly in urban areas of the Southeastern and Southern regions. The large number of unemployed people among the beneficiaries reveals their social vulnerability. Also shown was a high rate of social assistance benefits directed to urban dwellers, women, the young and elderly, and residents of the North and Northeast.

The social security system in Brazil faces its greatest crisis due to an aging

\section{REFERENCES}

to antiretroviral medication in people with HIV. Acta Paul Enferm. 2015. 28(1):48-53.

12. Miranda GMD, Mendes A da CG, Silva ALA. Population aging in Brazil: current and future social challenges and consequences. Rev Bras Geriatr Gerontol. 2016;19(3):507-19.

13. Okuno MFP, Gomes AC, Meazzini L, Scherrer Júnior $G$, Belasco Junior $D$, Belasco AGS. Qualidade de vida de pacientes idosos vivendo com HIV / AIDS. Cad Saude Publica. 2014;30(7):1551-9.

14. Teixeira TR de A, Gracie R, Malta MS, Bastos FI. Social geography of AIDS in Brazil: identifying patterns of regional inequalities. Cad Saude Publica. 2014;30(2):259-71.

15. Instituto Brasileiro de Geografia e Estatística. Sinopse do Censo Demográfico 2010 Brasil. População nos Censos Demográficos, segundo as Grandes Regiões, as Unidades da Federação e a situação do domicílio 1960/2010. Available from: www.censo2010. ibge.gov.br/sinopse/index.php?dados$=8 \& u f=00$ Accessed 23 June 2017.

16. Corseuil CH, Reis MC, Brito AS. Critérios de classificação para ocupação informal: Consequências para a caracterização do setor informal e para a análise de bem-estar no Brasil. Estud Econ. 2015;45(1):5-31.

17. Organização Internacional do Trabalho (OIT). Mulheres no Trabalho: Tendências 2016. Geneva: OIT; 2016. Available from: www.ilo.org/wcmsp5/groups/public/--dgreports/---dcomm/--publ/documents/publication/wcms_457096.pdf Accessed 23 June 2017.

18. Moreira JP de L, Oliveira BLCA de, Muzi CD, Cunha CLF, Brito A dos S, Luiz RR. A saúde dos trabalhadores da atividade rural no Brasil. Cad Saude Publica. 2015;31(8):1698-1708.

19. Laurenti R, Jorge MHP de M, Gotlieb SLD. Perfil epidemiológico da morbi-mortalidade masculina. Cien Saude Colet. 2005;10(1):35-46.

20. Greco DB. Thirty years of confronting the Aids epidemic in Brazil, 1985-2015. Cien Saude Colet. 2016;21(5):1553-64.

21. Brasil. Benefícios assistenciais 2015. Available from: http://mds.gov.br/as- population, early retirement, and social security fraud, among others. The control of diseases that are debilitating due to physical, moral, and social incapacity should be a top priority for the social welfare system. Controlling AIDS will minimize the social impact to the country on all levels.

\section{Conflict of interests. None declared.}

Disclaimer. Authors hold sole responsibility for the views expressed in the manuscript, which may not necessarily reflect the opinion or policy of the RPSP/ $\mathrm{PAJPH}$ and/or PAHO. suntos/assistencia-social/beneficios-assistenciais Accessed 3 March 2018.

22. Brasil. Ministério Da Saúde. Protocolo clinico e diretrizes terapêuticas para manejo da infecção pelo HIV em adultos. Brasília: Ministério da Saúde; 2013.

23. Lago RF, Costa NR. Expert communities and interest-formation in the Brazilian AIDS program. Cien Saude Colet. 2017;22(5):1479-88.

24. Nakagawa F, May M, Phillips A. Life expectancy living with HIV: Recent estimates and future implications. Curr Opin Infect Dis. 2013;26(1):17-25.

25. Joint UN Programme on HIV/AIDS. Ending AIDS: Progress towards the 90-9090 targets. UNAIDS; 2017. Available from: http://www.unaids.org/en/resources / documents/2017/20170720_Global_AIDS_ update_2017. Accessed 10 August 2017.

26. Brasil. Ministério do Trabalho e Emprego. Portaria $\mathrm{N}^{\mathrm{o}}$ 1246, de 28 de maio de 2010. Diário Oficial da União, Brasília, DF; 31 May. 2010. Available from: www.trtsp. jus.br/geral/tribunal2 /ORGAOS/ MTE/Portaria/P1246_10.html Accessed 28 February 2018.

27. Brasil. Turma Nacional de Uniformização dos Juizados Especiais Federais. SUM-78. Comprovado que o requerente de benefício é portador do vírus HIV, cabe ao julgador verificar as condições pessoais, sociais, econômicas e culturais, de forma a analisar a incapacidade em sentido amplo, em face da elevada estigmatização social da doença. Brasília, 11 de setembro de 2014. Available from: www.cjf.jus.br/cjf/ noticias / 2014/setembro/tnu-aprova-sumula-78 Accessed 28 February 2018.

28. Grangeiro A, Escuder MML, Castilho EA. A epidemia de AIDS no Brasil e as desigualdades regionais e de oferta de serviço. Cad Saude Publica. 2010;26(12):2355-67.

Manuscript received on 28 September 2017. Accepted for publication on 12 March 2018 
RESUMEN Objetivo. Describir la distribución de las prestaciones en materia de bienestar social relacionadas con el sida en Brasil y comparar las características de los beneficiarios de la asistencia social y la seguridad social entre el 2004 y el 2016.

El bienestar social relacionado con el sida en Brasil: factores asociados con la asistencia social y la seguridad social, 2004-2016

Métodos. Estudio de observación y analítico basado en datos secundarios obtenidos del Ministerio de Seguridad Social de Brasil. Se analizaron las características sociodemográficas y epidemiológicas de los beneficiarios de la asistencia social y la seguridad social relacionadas con el sida.

Resultados. Entre el 2004 y el 2016 se otorgó un total de 99369 prestaciones, de las cuales $64 \%$ fueron pagos por enfermedad, seguidos de prestaciones de la asistencia social $(26,5 \%)$ y pensiones por incapacidad $(8,1 \%)$. En el momento que se iniciaron las prestaciones, $51 \%$ de las personas estaban desempleadas. Los residentes en zonas urbanas, las mujeres, los jóvenes, los adultos mayores y los residentes del norte y el nordeste recibieron más prestaciones de la asistencia social. La duración de las prestaciones de la asistencia social (en promedio, 4589 días) fue mayor que la de las prestaciones de la seguridad social (302 días). La supervivencia en las mujeres (578 meses) fue mayor que en los hombres (311 meses).

Conclusiones. En el Brasil, el perfil de los beneficiarios de los programas de bienestar social que tienen sida muestra su vulnerabilidad social. Controlar el sida debe ser una prioridad entre los asuntos de interés público, a fin de reducir al mínimo sus repercusiones sociales y económicas, especialmente en materia de salud pública, seguridad social y asistencia social.

Palabras clave Síndrome de Inmunodeficiencia Adquirida; VIH; bienestar social; seguridad social; Brasil.

RESUMO

Bem-estar social das pessoas com HIV/aids no Brasil: fatores associados à assistência social $\mathbf{e}$ previdência social, 2004-2016

Palavras-chave
Objetivo. Descrever a concessão de benefícios do sistema de seguridade social a pessoas com HIV/aids no Brasil e comparar as características dos beneficiários assistenciais e previdenciários no período de 2004 a 2016.

Métodos. Estudo observacional analítico conduzido com dados secundários obtidos do Ministério da Previdência Social do Brasil. Foram analisadas as características sociodemográficas e epidemiológicas dos beneficiários assistenciais e previdenciários portadores de HIV/aids.

Resultados. Foram concedidos ao todo 99.369 benefícios no período 2004-2016, entre eles auxílio-doença (64\%), benefícios de assistência social $(26,5 \%)$ e aposentadoria por invalidez $(8,1 \%)$. Ao início da vigência dos benefícios, 51\% dos beneficiários estavam desempregados. Pessoas residentes em áreas urbanas, do sexo feminino, jovens, idosos e vivendo nas Regiões Norte e Nordeste foram os maiores beneficiários de benefícios assistenciais. A vigência dos benefícios assistenciais (média de 4.589 dias) foi maior que à dos benefícios previdenciários (302 dias). A sobrevida no sexo feminino (578 meses) foi superior à observada no sexo masculino (311 meses).

Conclusões. O perfil dos beneficiários do sistema de bem-estar social revela que as pessoas vivendo com HIV/aids no Brasil estão em estado de vulnerabilidade social. O controle do HIV/aids deve ser prioridade entre as questões de interesse público a fim de reduzir ao mínimo a repercussão socioeconômica da doença, sobretudo na saúde pública, assistência social e previdência social.

Síndrome de Imunodeficiência Adquirida; HIV; previdência social; seguridade social; Brasil. 